\title{
Identification and Utility of Markers Linked to the Zucchini Yellow Mosaic Virus Resistance Gene in Watermelon
}

\author{
Karen R. Harris ${ }^{1}$, Kai-Shu Ling, W. Patrick Wechter, and Amnon Levi ${ }^{2}$ \\ U.S. Department of Agriculture-Agricultural Research Service, U.S. Vegetable Laboratory, 2700 \\ Savannah Highway, Charleston, SC 29414
}

\begin{abstract}
ADDITIONAL INDEX wORDs. Citrullus, inheritance, recessive, potyvirus, marker-assisted selection, CAPS, SNP, SCAR
Abstract. Zucchini yellow mosaic virus (ZYMV) is one of the most economically important viruses affecting watermelon [Citrullus lanatus (Thunb.) Matsun \& Nakai var. lanatus] in the United States. The ZYMV-Florida strain (ZYMV-FL) is considered a major limitation to commercial watermelon production in the United States. Inheritance of resistance to $\mathrm{ZYMV-FL}$ is conferred by a recessive gene. This report describes the identification of single-reaction, polymerase chain reaction-based markers linked to the ZYMV-FL resistance gene in watermelon. In this study, we identified a marker ZYMV-resistant polymorphism (ZYRP) linked to the ZYMV-FL resistance gene locus (genetic distance of $8 \mathrm{cM})$ in an $\mathrm{F}_{2}$ population, and in a backcross one to the resistant parent population $\left(\mathrm{BC}_{1} \mathrm{R}\right)(\mathrm{genetic}$ distance of $13 \mathrm{cM}$ ). The identification of a single nucleotide polymorphism within the ZYRP marker for the parental genotypes allowed the development of a sequence-characterized amplification region marker linked to the ZYMV-FL resistance gene. Experiments using a $\mathrm{BC}_{2} \mathrm{~F}_{2}$ population derived from the U.S. Plant Introduction 595203 (C. lanatus var. lanatus) and the recurrent parent 'Charleston Gray' indicated that the ZYRP marker can be used in markerassisted selection to identify genotypes containing the gene conferring ZYMV-FL resistance in watermelon.
\end{abstract}

Watermelon is an economically important crop with over 1.9 billion kilograms produced in the United States in 2006, with a fresh market value of $\$ 434$ million [U.S. Department of Agriculture (USDA), 2007]. Potyviruses are a major limiting factor of commercial watermelon production worldwide (Huttner et al., 2001). Viruses that affect watermelon include papaya ringspot virus-watermelon strain (PRSV-W), watermelon mosaic virus (WMV), and ZYMV (Guner and Wehner, 2008; Strange et al., 2002). All three viruses are difficult to control and are spread by aphids (e.g., Aphis gossypii Glover). Infection by more than one of these viruses is common in cucurbit plants (Davis and Mizuki, 1987). Plants infected with these viruses lose their photosynthetic capacity, and display stunted growth, deformed fruit, and early mortality (Guner and Wehner, 2008; Sherf and Macnab, 1986).

The ZYMV infects cucurbit crops, including melon (Cucumis melo L.), cucumber (Cucumis sativus L.), watermelon, squash (Cucurbita maxima Duchesne, Cucurbita moschata Duchesne), and pumpkin (Cucurbita pepo L.) (Gal-on, 2007). The severity of infection depends on temperature, plant age, and the strain of ZYMV (Guner, 2004). The ZYMV was first identified in squash in northern Italy (Lisa and Dellavalle, 1981) and has spread to the major cucurbit-producing regions throughout the world (Guner, 2004). Two predominant ZYMV strains have been identified in the United States. They are the ZYMV-Connecticut strain (ZYMV-CT) and ZYMV-Florida strain (ZYMV-FL) (Provvidenti et al., 1984). The ZYMV-FL is the most predominant strain

Received for publication 18 June 2009. Accepted for publication 2 Sept. 2009. We thank Andrea Gilliard and Emily Walter for their technical assistance. We also thank Dr. Umesh Reddy for providing the sequence of the SSR primers used in this study.

${ }^{1}$ U.S. Department of Agriculture-Agricultural Research Service, Crop Genetics and Breeding Research, 115 Coastal Way, Tifton, GA 31793.

${ }^{2}$ Corresponding author. E-mail: Amnon.Levi@ars.usda.gov. in the United States, whereas ZYMV-CT is limited to the northeastern U.S. (Provvidenti et al., 1984). In 1991, the ZYMV-China (ZYMV-CH) strain was collected from severely infected cucurbit fields near Beijing, China.

A number of strategies have been employed to control the spread of viruses in agricultural crops. These strategies include the use of insecticides to reduce the infestation of virus vectors (Mutschler and Wintermantel, 2006), the use of a mild or attenuated virus strain to protect the plant from the virulent strain (cross-protection) (McKinney, 1929), and genetic modification of plants (Prins et al., 2008). However, the most economically and publicly accepted method to control viruses is achieved by plant breeding with lines that are genetically resistant (Mutschler and Wintermantel, 2006; Xu et al., 2004). The U.S. Plant Introduction accessions (PIs) of watermelon maintained at the U.S. Department of Agriculture, Agricultural Research Service (ARS), Plant Genetic Resources and Conservation Unit (PGRCU), Griffin, GA, were screened for ZYMVFL resistance (Guner, 2004; Provvidenti, 1991). Provvidenti (1991) identified the C. lanatus var. citroides (L.H. Bailey) Mansf. PI 482322, PI 482299, PI 482308, and PI 482261 as resistant to ZYMV-FL. Resistance to ZYMV-FL in PI 482261 is conferred by a single recessive gene, zym (Provvidenti, 1991). Also, the C. lanatus var. lanatus PI 595203 was identified as a source of ZYMV-FL and ZYMV-CH resistance (Boyhan et al., 1992; Guner, 2004; Xu et al., 2004). Resistance to ZYMV-FL and ZYMV-CH in PI 595203 is conferred by a single recessive gene (Ling et al., 2008) and the resistance gene to ZYMV-CH was designated zym-CH (Xu et al., 2004). Whether the ZYMV-CH and ZYMV-FL strains are the same or whether the two resistance genes are the same has not been previously determined (Xu et al., 2004).

For the introgression of the recessive ZYMV resistance gene into cultivated lines, molecular markers could prove useful as they would accelerate the breeding process by eliminating the 
need for an additional self-pollination step in each backcross to an elite cultivar, normally required to select for those plants that would be homozygous for the recessive ZYMV resistance gene. In a recent study, we developed two cleaved amplified polymorphic sequence (CAPS) markers, CAPS-1 and CAPS-2, within the eukaryotic translation initiation factor 4E (eIF4E) gene sequence of watermelon (Ling et al., 2008). Studies with tomato (Solanum lycopersicum L.) and pepper (Capsicum annuum L.) plants have shown that a mutation in the eIF4E gene may confer resistance to several potyviruses (Robaglia and Caranta, 2006; Ruffel et al., 2005). CAPS-1 and CAPS-2 markers are linked to the ZYMV-FL resistance gene locus in PI 595203 , having a genetic distance of 6 and $10 \mathrm{cM}$ in an $\mathrm{F}_{2}$ population derived from the ZYMV-resistant PI 595203 and the ZYMV-susceptible cultivar New Hampshire Midget (NHM) and in a backcross one to the resistant parent population [(PI $595203 \times$ 'NHM') PI 595203], respectively (Ling et al., 2008). Studies indicate that when no allele-specific marker has been established, a set of several markers, representing the genomic region containing the gene of interest, should produce high selection efficiency for marker-assisted selection (MAS) (Cai et al., 2003; Yi et al., 2008). In this study, we sought to identify and develop additional markers linked to the ZYMV-FL resistance gene locus using bulk segregant analysis, to map the markers in reference to the gene conferring ZYMV-FL resistance and in reference to the eIF4E gene that we previously identified as closely linked to this resistance gene (Ling et al., 2008), and to ascertain the utility of the markers, including the eIF4E-CAPS markers and the markers identified here, in breeding programs using MAS to incorporate the ZYMV-FL resistance gene into the genomic background of a watermelon cultivar.

\section{Materials and Methods}

\section{Plant material, virus isolation, inoculation,} and symptom evaluation

Seedlings from watermelon cultivars Black Diamond, Charleston Gray, Jubilee, and NHM were used in this study. Seeds of C. lanatus var. citroides PI 482261, PI 482299, PI 482308, and PI 482323 were obtained from the USDA, ARS, Southern Regional Plant Introduction Station at Griffin, GA. The $\mathrm{F}_{1}, \mathrm{~F}_{2}$, and reciprocal $\mathrm{BC}_{1} \mathrm{R}$ populations, derived from a cross between PI 595203 (ZYMV resistant) and 'NHM' (ZYMV susceptible) were developed at North Carolina State University, Raleigh (Guner, 2004). DNA samples were prepared for bulked segregant analysis by combining the 10 most susceptible and the 10 resistant $\mathrm{F}_{2}$ individuals into separate bulks, as described by Michelmore et al. (1991).

The ZYMV-FL isolate was obtained from T.C. Wehner (North Carolina State University, Raleigh). The inoculation of plants with ZYMV-FL, the quantification of virus replication by ELISA, the visual scoring for virus symptoms, and the extraction of DNA from plants were as described previously (Ling et al., 2008).

\section{Screening markers for polymorphism and for linkage with the ZYMV-FL resistance gene}

Twenty-four markers that were previously mapped on linkage group XIV (Levi et al., 2006) were screened for polymorphism between PI 595203 and 'NHM'. In addition, 257 single sequence repeats (SSRs), 591 randomly amplified polymorphic DNA markers (RAPDs), 69 sequence related amplified polymorphisms (SRAPs), 30 target region amplification polymorphisms (TRAPs), and two expressed sequence tags (ESTs), were tested for polymorphism between the ZYMV-resistant PI 595203 and 'NHM'. The polymerase chain reaction (PCR) amplification procedures for the RAPD, SRAP, TRAP, and EST primers were amplified as previously described (Levi et al., 2002, 2006).

The SSR markers were amplified and fluorescently labeled in a final reaction volume of $10 \mu \mathrm{L}$ using the following components: $2 \mu \mathrm{L}$ of $5 \times$ Colorless GoTaq Flexi Buffer (Promega, Madison, WI), $1 \mu \mathrm{L}$ of $25 \mathrm{~mm} \mathrm{MgCl}_{2}, 0.8 \mu \mathrm{L}$ of $2.5 \mathrm{~mm}$ dNTPs, $1 \mu \mathrm{L}$ of $5 \mu \mathrm{M}$ forward primer labeled with a D4 fluorophore, $1 \mu \mathrm{L}$ of $5 \mu \mathrm{M}$ reverse primer, $0.1 \mu \mathrm{L}$ GoTaq Flexi DNA Polymerase (Promega) at $5 \mathrm{U} / \mu \mathrm{L}, 3.1 \mu \mathrm{L}$ of water, and 1 $\mu \mathrm{L}$ of genomic DNA at $10 \mathrm{ng} \cdot \mu \mathrm{L}^{-1}$. The parameters for PCR were $95^{\circ} \mathrm{C}$ for $2 \mathrm{~min}$ followed by 35 cycles at $95^{\circ} \mathrm{C}$ for $60 \mathrm{~s}$, $50{ }^{\circ} \mathrm{C}$ for $45 \mathrm{~s}, 72{ }^{\circ} \mathrm{C}$ for $60 \mathrm{~s}$, and a final extension of $72{ }^{\circ} \mathrm{C}$ for $5 \mathrm{~min}$. The PCR products were resolved by capillary electrophoresis on a Beckman Coulter CEQ8800 Genetic Analysis System (Beckman Coulter, Fullerton, CA) using the fragment 3 parameters.

Gel eXtraction, Cleanup, ClONing, AND SEQUenCing OF A POLYMORPHIC MARKER (DESIGNATED AS ZYRP) LINKED TO THE ZYMV RESISTANCE GENE. The following primer pair ZYRP-1-F (5'-CGAGCAAGAAATCACTGCCCAG-3') and ZYRP221-R (5'-CGCTG TTTCACGCTTCTGTCGC-3') was used to amplify the desired fragments from genomic DNA of 'NHM' and PI 595203 using the PCR conditions described above for SSR markers. The PCR products were resolved by electrophoresis on a $2 \%$ agarose gel, and the desired fragments were gel extracted and cleaned with a Wizard SV Gel and PCR Clean-Up System (Promega) from each genotype. The PCR products were cloned into a pCR2.1-TOPO vector using the TOPO TA Cloning Kit (Invitrogen, Carlsbad, CA). Sequencing was performed using the GenomeLab Dye Terminator Cycle Sequencing with Quick Start Kit (Beckman Coulter) on the Beckman Coulter CEQ8800 DNA Genetic Analysis System.

GENERATION OF A ZYRP-SCAR MARKER FOR IDENTIFYING POLYMORPHISM USING CAPILLARY ELECTROPHORESIS. A sequencecharacterized amplification region (SCAR) marker was generated based on the single nucleotide polymorphism (SNP) at base pair 190. The primers used were designated ZYRP-80-F (5' TGTAAAACGACGGCCAGTAGAGCGAGATGCAACG AGAG-3') and ZYRP-216-R (5' -ACGCTTCTGTCGCTCAG AGT-3'). The ZYRP SCAR was amplified and fluorescently labeled in a final reaction volume of $10 \mu \mathrm{L}$ using the following components: $2 \mu \mathrm{L}$ of $5 \times$ Colorless GoTaq Flexi Buffer (Promega Corp.), $0.6 \mu \mathrm{L}$ of $25 \mathrm{~mm} \mathrm{MgCl}_{2}, 0.8 \mu \mathrm{L}$ of $2.5 \mathrm{~mm}$ dNTPs, $0.5 \mu \mathrm{L}$ of $5 \mu \mathrm{M}$ ZYRP-80-F primer labeled with a M13 tag, $2 \mu \mathrm{L}$ of $5 \mu \mathrm{M}$ ZYRP-216-R primer, $1.8 \mu \mathrm{L}$ of $1 \mu \mathrm{M} \mathrm{M} 13$ labeled with a D3 fluorophore, $0.1 \mu \mathrm{L}$ of Promega GoTaq Flexi DNA Polymerase at $5 \mathrm{U} / \mu \mathrm{L}$ (Promega Corp.), $1.2 \mu \mathrm{L}$ of water, and $1 \mu \mathrm{L}$ of genomic DNA at $10 \mathrm{ng} \cdot \mu \mathrm{L}^{-1}$. The parameters for PCR were 37 cycles at $95^{\circ} \mathrm{C}$ for $1 \mathrm{~min}, 57^{\circ} \mathrm{C}$ for $1 \mathrm{~min}$, and $72{ }^{\circ} \mathrm{C}$ for $1 \mathrm{~min}$. The PCR products were separated on the Beckman Coulter CEQ8800 Genetic Analysis System.

\section{Genetic mapping of the ZYRP marker}

The ZYRP marker was amplified from a $\mathrm{F}_{2}\left(143 \mathrm{~F}_{2}\right.$ individuals) and a $\mathrm{BC}_{1} \mathrm{R}\left(117 \mathrm{BC}_{1} \mathrm{R}\right.$ individuals) population 
derived from PI 595203 and 'NHM'. The ZYRP marker segregation data in the $\mathrm{F}_{2}$ and $\mathrm{BC}_{1} \mathrm{R}$ population were entered into a text file that contained segregation data for the CAPS-1 and CAPS-2 markers (which are linked to the eIF4E gene), and for the ZYMV resistance and susceptible phenotypes (Ling et al., 2008). Linkage analysis was performed using JoinMap version 3.0 software (Van Ooijen and Vooripps, 2001), as previously described (Levi et al., 2006), and a log of the odds ratio (LOD) score of 2 was used for grouping.

\section{Genetic mapping of ZYRP on a testcross map constructed for watermelon}

ZYRP was mapped using a testcross population $\{88$ testcross progeny [Griffin 14113 (C. lanatus var. citroides) $\times$ 'NHM' (C. lanatus var. lanatus)] $\times$ PI 386015 [C. colocynthis (L.) Schrad.]\} (Levi et al., 2002, 2006). Linkage analysis was performed using JoinMap version 3.0 software (Van Ooijen and Vooripps, 2001) using previously described conditions (Levi et al., 2006) except that a minimum LOD score of 9 was used for grouping.

\section{Assessing the utility of a marker set (including ZYRP and CAPS-1 or CAPS-2) in identifying ZYMV-FL-resistant $\mathrm{BC}_{2} \mathrm{~F}_{2}$ plants}

Thirty-eight $\mathrm{BC}_{2} \mathrm{~F}_{2}$ plants were generated by first backcrossing a $Z$ YMV-FL-resistant $\mathrm{F}_{3}$ plant (derived from a cross PI $595203 \times$ 'Charleston Gray') with the recurrent parent 'Charleston Gray'. After each backcrossing, the CAPS-1 and CAPS-2 markers (Ling et al., 2008) and the ZYRP marker, identified here, were used to select for those progeny that presumably contain the PI 595203 allele conferring ZYMV-FL resistance. $\mathrm{A} \mathrm{BC}_{2} \mathrm{~F}_{1}$ plant that contains the PI 595203 allele for the CAPS and ZYRP marker was then self-pollinated to produce $\mathrm{BC}_{2} \mathrm{~F}_{2}$ plants. Thirty-eight $\mathrm{BC}_{2} \mathrm{~F}_{2}$ plants were inoculated twice with ZYMV-FL (at 15 and 18 d post-germination), as described by Ling et al. (2008). Three weeks following the second inoculation, the plants were scored for virus symptoms as follows: $0=$ complete immunity/no virus symptoms, 1 = slight yellow mosaic on the systemic leaves, $2=$ slightly deformed apical leaves with yellow mosaic, $3=$ severely deformed apical leaves with mosaic appearance; $4=$ extensive mosaic appearance and severe leaf deformation, $5=$ plant death. Leaf samples were collected from each of the $38 \mathrm{BC}_{2} \mathrm{~F}_{2}$ plants and used for quantifying virus replication by ELISA, as described by Ling et al. (2008). Leaf samples were also used for isolation of DNA that was used for genotyping with the CAPS-1, CAPS-2, and ZYRP markers.

The genotyping of the $\mathrm{BC}_{2} \mathrm{~F}_{2}$ plants with CAPS- 1 and CAPS-2 was as described by Ling et al. (2008). The CAPS-1 marker was amplified using the primer pair KL07-75, 5' CCAACAGCAAGAACCGAAAG and KL07-76, 5' TTTGGTTCGATAACCCATCC and the CAPS-2 marker was amplified using the primer pair KL08-03, 5' -AAAG CTACAC CCACGGAAGA and KL08-04, 5'-CTCCAGAACTCCTCG ACAGTAG. The markers were PCR amplified in a final reaction volume of $20 \mu \mathrm{L}$ using the following components: 4 $\mu \mathrm{L}$ of $5 \times$ Green GoTaq Flexi Buffer (Promega), $2 \mu \mathrm{L}$ of $25 \mathrm{~mm}$ $\mathrm{MgCl}_{2}, 1.6 \mu \mathrm{L}$ of $2.5 \mathrm{~mm}$ dNTPs, $2 \mu \mathrm{L}$ of KL07-75/76 or KL08-03/04 primers at $2 \mu \mathrm{M}, 0.1 \mu \mathrm{L}$ GoTaq Flexi DNA Polymerase at $5 \mathrm{U} / \mu \mathrm{L}$ (Promega), $9.3 \mu \mathrm{L}$ of water, and $1 \mu \mathrm{L}$ of genomic DNA at $10 \mathrm{ng} \cdot \mu \mathrm{L}^{-1}$. The parameters for PCR were $95^{\circ} \mathrm{C}$ for $2 \mathrm{~min}$ followed by 34 cycles at $95^{\circ} \mathrm{C}$ for $1 \mathrm{~min}, 50^{\circ} \mathrm{C}$ for $45 \mathrm{~s}, 72{ }^{\circ} \mathrm{C}$ for $1 \mathrm{~min}$, and a final cycle at $72{ }^{\circ} \mathrm{C}$ for $5 \mathrm{~min}$.
Digestion of $10 \mu \mathrm{L}$ of the KL07-75/76 amplicon with MseI was performed by adding $1.5 \mu \mathrm{L}$ of $10 \times$ Buffer 2 (NEB, Ipswich, MA), $1.5 \mu \mathrm{L}$ of NEB $100 \times$ BSA, and $0.1 \mu \mathrm{L}$ of NEB $M s e I$ at $50,000 \mathrm{U} / \mathrm{mL}$ into a $1.5-\mathrm{mL}$ microcentrifuge tube. The reactions were placed in a $37^{\circ} \mathrm{C}$ water bath for $1 \mathrm{~h}$ and later heat inactivated in a $65^{\circ} \mathrm{C}$ water bath for $20 \mathrm{~min}$. Digestion of $10 \mu \mathrm{L}$ of the KL08-03/04 amplicon with PasI (Fermentas, Glen Burnie, MD) was performed by adding $19 \mu \mathrm{L}$ of water, $2 \mu \mathrm{L}$ of $10 \times$ PasI buffer (Fermentas), and $0.02 \mu \mathrm{L}$ of $P$ asI at $10 \mathrm{U} / \mu \mathrm{L}$ into a $1.5 \mathrm{~mL}$-microcentrifuge tube. The reactions were placed in a $55^{\circ} \mathrm{C}$ water bath for $16 \mathrm{~h}$ and were later heat inactivated by placing the reactions in an $80{ }^{\circ} \mathrm{C}$ water bath for $20 \mathrm{~min}$. Digested amplicons were separated using a $1.25 \%$ agarose gel for the KL08-03/04 digestion reactions and a 2\% agarose gel for KL07-75/76 digestion reactions. Electrophoresis was performed in $1 \times$ SB buffer (Brody and Kern, 2004) at $178 \mathrm{~V}$ for $1 \mathrm{~h}$, and DNA was visualized using ethidium bromide.

\section{Results and Discussion}

SCREENING AND IDENTIFICATION OF A MARKER LINKED TO THE ZYMV-FL RESISTANCE GENE. The 949 primers (RAPD, SRAP, SSR, TRAP, and EST) tested in this study yielded 150 polymorphic markers between the ZYMV-resistant PI 595203 and the susceptible cultivar NHM. The low polymorphism rate $(15.8 \%)$ is consistent with previously published data, confirming that genetic difference is quite small within C. lanatus var. lanatus (Levi et al., 2001, 2002). Furthermore, because the PI 595203 allele that conditions resistance to ZYMV-FL is homozygous recessive, only polymorphic markers that are dominant for 'NHM' or codominant could be useful for bulked segregant analysis between the 'NHM' and PI $595203 \mathrm{~F}_{2}$ resistant and -susceptible bulks. The 150 polymorphic markers were tested using bulked segregant analysis to identify a marker(s) linked to the gene conferring ZYMV-FL resistance. Of these 150 polymorphic markers, one marker was identified as linked to the ZYMV-resistance gene and was designated as 'ZYRP'.

The capillary electrophoresis chromatograms, generated on the Beckman Coulter CEQ 8800, indicated that the ZYRP size is 221 and 219 bp in PI 595203 and 'NHM', respectively (data not shown). However, subsequent sequence analysis revealed that the ZYRP marker is the same size (221 bp) in PI 595203 and 'NHM' (Fig. 1). The apparent size difference is likely the result of a SNP where, at the 190 nucleotide position, the nucleotide cytosine in 'NHM' is substituted by a thymine in PI 595203 (Fig. 1). The SNP at the 190 position likely affects the DNA secondary structure (Inazuka et al., 1997), causing an apparent 2-bp difference in migration through the capillary polymer. To generate a set of primers that amplify a single fragment linked to the ZYMV-FL resistance gene, as opposed to primers ZYRP-1-F and ZYRP-221-R, which amplify six fragments, a new primer pair (ZYRP-80-F and ZYRP-216-R) was developed (Fig. 1). The amplicon generated with this new primer set produced a gel migration polymorphism of 155 and $153 \mathrm{bp}$ (inclusive of the 18-bp M13 tag) for PI 595203 and 'NHM', respectively. The ZYRP SCAR marker is easily produced through a single amplification reaction. Basic local alignment search tool analysis revealed that the 221-bp ZYRP sequence (Fig. 1) has no significant homology to any known sequence published in the National Center for Biotechnology Information database. 
Genetic MAPPING OF THE ZYRP MARKER IN REFERENCE TO THE ZYMV-FL RESISTANCE GENE. ZYRP was mapped at 2 and $3 \mathrm{cM}$ from the eIF4E gene and 8 and 13 $\mathrm{cM}$ from the ZYMV-FL resistance gene in the $F_{2}$ and $B_{1} R$ populations, respectively (Table 1; Fig. 2). The difference in genetic distance between the $\mathrm{F}_{2}$ and the $\mathrm{BC}_{1} \mathrm{R}$ populations is not remarkable and is likely due to the difference in the size of the genetic populations (having $143 \mathrm{~F}_{2}$ Vs. $117 \mathrm{BC}_{1} \mathrm{R}$ progenies). Genetic mapping in rice (Oryza sativa L.) has indicated that distances between markers will change with population size (Rangel et al., 2007).

Using the testcross mapping population constructed for watermelon (Levi et al., 2002, 2006), ZYRP was mapped on linkage group XIV, between UBC595-725c and the eIF4E CAPS-1 markers (Fig. 2).

Assessing THE UTILITy OF THE ZYRP, CAPS-1 AND CAPS-2 MARKERS FOR USE IN MARKERASSISTED SELECTION TO IDENTIFY GENOTYPES POSSESSING THE ZYMVFL RESISTANCE ALLELE. In our previous study (Ling et al., 2008), we described the CAPS-1 and CAPS-2 markers located in the eIF4E gene, but did not determine their usefulness in MAS programs. Here, we tested $38 \mathrm{BC}_{2} \mathrm{~F}_{2}$ plants inoculated with ZYMV-FL for the presence or absence of the CAPS and ZYRP markers. Of the 38 plants tested, 21 exhibited an extensive mosaic appearance and severe leaf deformation (rating of 4), five had deformed apical leaves with mosaic appearance (rating of 3), one had slightly deformed apical leaves with yellow mosaic (rating of 2), and 11 had very slight yellow mosaic on early leaves (rating of 1) (Fig. 3 ). Of the 21 plants that were rated as 4,13 were heterozygous, and eight were homozygous for the CAPS-1, CAPS-2, and ZYRP alleles of 'Charleston Gray'. Of the five plants that had rating of 3, two were homozygous for the CAPS-1, CAPS-2, and ZYRP alleles of PI 595203, while two were heterozygous and one was homozygous for the 'Charleston Gray' alleles. Of the two plants that had a rating of 2, one was homozygous and heterozygous for the PI 595203 allele. All 11 plants with a rating of 1 had no or very slight viral symptoms were homozygous for the CAPS-1, CAPS-2, and ZYRP alleles of PI 595203 (Fig. 3). ELISA analysis showed that all $11 \mathrm{BC}_{2} \mathrm{~F}_{2}$ plants rated as a 1 supported viral replication (ELISA viral replication score range of $0.170-0.423$ ) comparable to that of the susceptible watermelon plant 'Crimson Sweet' (ELISA viral replication score of 0.298 ), and in contrast with PI 595203 (ELISA viral replication score of 0.005). Since the $\mathrm{BC}_{2} \mathrm{~F}_{2}$ plants generated did not contain the same level of resistance found in PI 595203, as very mild symptoms and virus replication were detected on most resistant plants, it is possible that a modifier gene controlling ZYMV-FL replication may exist in 'Charleston Gray'. Thus, the CAPS and ZYRP markers are linked to a gene that conditions resistance to the ZYMV-FL strain, but replication of the virus occurs in plants that were backcrossed to the cultivar Charleston Gray. Therefore, the cultivar used as the recurrent parent is important as ZYMV-FL resistance in a $\mathrm{BC}_{1} \mathrm{R}$, derived from PI 595203 and the backcross parent 'NHM', segregated as a single recessive gene. Further genetic studies are needed to confirm the possibility that a modifier gene(s) may control replication of the ZYMV-FL strain in 'Charleston Gray'. The CAPS and ZYRP markers proved useful in MAS to incorporate the PI 595203 ZYMV-FL resistance gene into the cultivar Charleston Gray. These markers should be equally useful for incorporation of this gene into other breeding lines and cultivars using a MAS breeding approach.

Our experiments with markers (SCAR4 and AK13) that were reported to be linked to the $\mathrm{ZYMV}-\mathrm{CH}$ resistance gene in PI 595203 (Ma et al., 2006) indicated that they are not linked to the CAPS and the ZYRP markers or to the ZYMV-FL resistance gene (data are not shown). These results suggest that the ZYMV-FL and ZYMV-CH may be different strains, and that the resistance to these strains may be controlled by genes on different linkage regions. Resistance to different virus was observed in a pepper genotype possessing two genes that confer resistance to different strains of the potato potyvirus $Y$ 
A
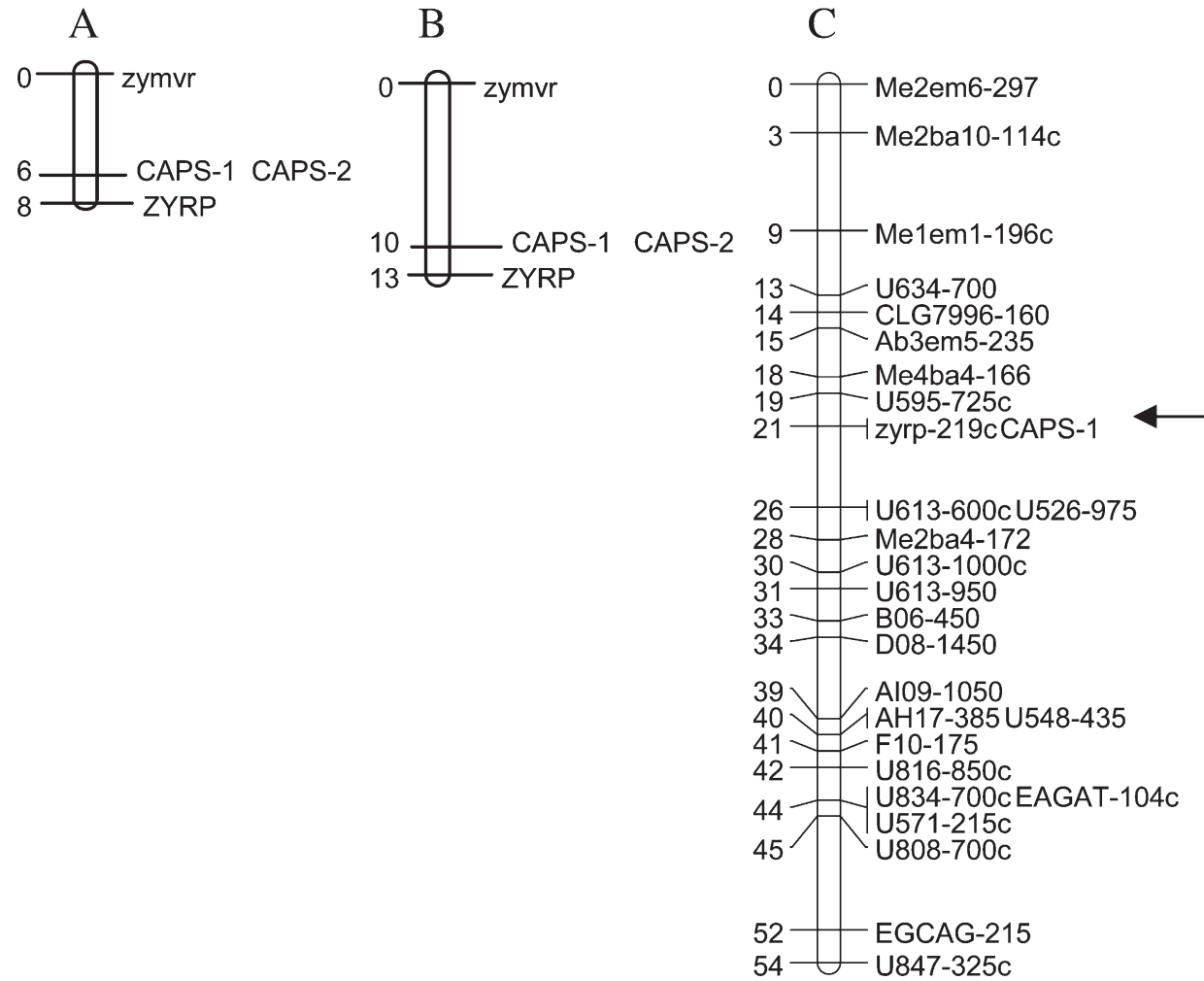

Fig. 2. (A) Genetic distance of the watermelon zucchini yellow mosaic virus Florida strain (ZYMV-FL) resistance gene, "zymvr," to the cleaved amplified polymorphic sequence (CAPS) and zucchini yellow mosaic virus resistant polymorphism $(Z Y R P)$ markers in a watermelon $F_{2}$ population $(N=143)$ derived from PI 595203 and 'New Hampshire Midget' ('NHM'). (B) Genetic distance of the ZYMV-FL resistance gene, "zymvr," to the CAPS markers and ZYRP markers in a $\mathrm{BC}_{1}$ population $(\mathrm{N}=117)$ derived from PI 595203 and ' $\mathrm{NHM}$ '. (C) Testcross linkage map $(\mathrm{N}=88)$ derived from Griffin 14113, 'NHM,' and PI 386015. The ZYMV-FL resistance gene linked markers CAPS-1 and ZYRP map to watermelon linkage group XIV. Primer name, allele size, and the parental origin of each polymorphic fragment are listed. When the amplified fragment is from 'NHM', the marker name is followed by a "c" (cultivar). Those markers listed without a "c" are derived from Griffin 14113. CAPS-1 is a codominant marker with a Griffin 14113 allele at base pair 187 and a 'NHM' allele at base pair 185. All other markers can be found in Levi et al. (2006). All distances shown are in centimorgans.
(Dogimont et al., 1996). If the ZYMV-CH and ZYMV-FL are indeed different strains, the identification of the resistance genes for these strains could allow breeders to pyramid the resistance genes from PI 595203 into a cultivated line, thus creating watermelon varieties with more durable resistant to ZYMV strains. PI 595203 has resistance to several potyviruses, including PRSV-W and WMV (Guner, 2004; Strange et al., 2002; Xu et al., 2004). The markers reported here as being linked to the ZYMV-FL resistance gene may also be useful in studies to determine if eIF4E is linked with resistance genes to PRSV-W and/or WMV in PI 595203.

Potyviruses are major limiting factor for most curcurbit crops. Mutation of eIF4E or eIF4G genes in many plant species is responsible for resistance to potyviruses (Robaglia and Caranta, 2006). A variant of the eIF4E gene results in resistance to the melon necrotic spot virus in $C$. melo (Nieto et al., 2006). DNA markers within the eIF4E gene could be tested for linkage to potyvirus resistance in different cucurbit crops. The eIF4E primers KL08-03/ 04 and KL07-75/76 described in Ling et al. (2008) produced the expected sized amplification products in three genera of Cucurbitaceae, Lageneria siceraria (Molina) Standl., C. lanatus var. citroides, $C$. lanatus var. lanatus, C. colocynthis, and C. maxima (data not shown). Likewise, it is also possible that the ZYRP sequence exists in the same genomic region that contains the eIF4E gene in other cucurbit species, and may be linked to potyvirus resistance in other cucurbit crops. Indeed, the ZYRP SCAR primers amplified DNA fragments in $C$. colocynthis and $C$. lanatus var. citroides, and in C. sativus (data not shown). However, further studies are needed to determine if these markers, linked to the ZYMV-FL resistance gene in watermelon, are also linked to potyvirus resistance genes in other cucurbits.

Conclusion. In this study, we identified the marker ZYRP that proved useful in selecting for the gene conferring ZYMVFL resistance in $\mathrm{BC}_{2} \mathrm{~F}_{2}$ population. The set of markers $\mathrm{ZYRP}$, CAPS-1, and/or CAPS-2 provide a robust marker combination for use in a MAS breeding program to identify genotypes containing the PI 595203 allele conferring ZYMV-FL resistance in watermelon cultivars.

\section{Literature Cited \\ Literature Cited} population derived from PI 595203 and 'Charleston Gray'. P/P = homozygous for PI 595203, P/C = heterozygous for PI 595203 and 'Charleston Gray', $\mathrm{C} / \mathrm{C}=$ homozygous for 'Charleston Gray' 1 = slight yellow mosaic on the systemic leaves, 2 = slightly deformed apical leaves with yellow mosaic, $3=$ severely deformed apical leaves with mosaic appearance; $4=$ extensive mosaic appearance and severe leaf deformation, or plant death.
Boyhan, G., J.D. Norton, B.J. Jacobsen, and B.R. Abrahams. 1992. Evaluation of watermelon and related germplasm for resistance to zucchini yellow mosaic virus. Plant Dis. 76:251-252. 
Brody, J.R. and S.E. Kern. 2004. Sodium boric acid: A tris-free, cooler conductive medium for DNA electrophoresis. Biotechniques 36:214-216.

Cai, H.W., Z.S. Gao, N. Yuyama, and N. Ogawa. 2003. Identification of AFLP markers closely linked to the $\mathrm{rhm}$ gene for resistance to southern corn leaf blight in maize by using bulked segregant analysis. Mol. Genet. Genomics 269:299-303.

Davis, R.F. and M.K. Mizuki. 1987. Detection of cucurbit viruses in New Jersey. Plant Dis. 71:40-44.

Dogimont, C., A. Palloix, A. Daubze, G. Marchoux, K. Selassie, and E. Pochard. 1996. Genetic analysis of broad spectrum resistance to potyviruses using doubled haploid lines of pepper (Capsicum annuum L.). Euphytica 88:231-239.

Gal-on, A. 2007. Zucchini yellow mosaic virus: Insect transmission and pathogenicity-the tail of two proteins. Mol. Plant Pathol. 8:139-150.

Guner, N. 2004. Papaya ringspot virus watermelon strain and zucchini yellow mosaic virus resistance in watermelon, Dept. Hort. Sci., North Carolina State Univ, Raleigh. Ph.D. Diss.

Guner, N. and T.C. Wehner. 2008. Overview of potyvirus resistance in watermelon. Cucurbitaceae 2008, Proc. IXth EUCARPIA Meeting on Genetics and Breeding of Cucurbitaceae. p. 445-451.

Huttner, E., W. Tucker, A. Vermeulen, F. Ignart, B. Sawyer, and R. Birch. 2001. Ribozyme genes protecting transgenic melon plants against potyviruses. Curr. Issues Mol. Biol. 3:27-34.

Inazuka, M., H. Wenz, M. Sakabe, T. Tahira, and K. Hayashi. 1997. A streamlined mutation system: Multicolor post-PCR fluorescence labeling and single-strand conformational polymorphism analysis by capillary electrophoresis. Genome Res. 7:1094-1102.

Levi, A., C.E. Thomas, A.P. Keinath, and T.C. Wehner. 2001. Genetic diversity among watermelon (Citrullus lanatus and Citrullus colocynthis) accessions. Genet. Resources Crop Evol. 48:559-566.

Levi, A., C.E. Thomas, T. Joobeur, X. Zhang, and A. Davis. 2002. A genetic linkage map for watermelon derived from a testcross population: (Citrullus lanatus var. citroides $\times$ C. lanatus var. lanatus) $\times$ Citrullus colocynthis. Theor. Appl. Genet. 105:555-563.

Levi, A., C.E. Thomas, T. Trebitsh, A. Salman, J. King, J. Karalius, M. Newman, O.U.K. Reddy, Y. Xu, and X. Zhang. 2006. An extended linkage map for watermelon based on SRAP, AFLP, SSR, ISSR, and RAPD markers. J. Amer. Soc. Hort. Sci. 131:393-402.

Ling, K.S., K.R. Harris, J.D.F. Meyer, A. Levi, N. Guner, T.C. Wehner, and M.J. Havey. 2008. Identification of a CAPS marker in an eIF4E gene linked to zucchini yellow mosaic virus resistance in watermelon. Cucurbitaceae 2008, Proc. IXth EUCARPIA Meeting on Genetics and Breeding of Cucurbitaceae. p. 213-218.

Lisa, V. and G. Dellavalle. 1981. Characterization of two potyviruses from zucchini squash. Phytopathology 100:279-286.

Ma, S., Y. Xu, H. Zhang, G. Gong, and H. Shen. 2006. Identification of the molecular markers linked to the resistance gene to zucchini yellow mosaic virus Chinese strain in watermelon. Acta Phytopathologica Sin. 36:68-73.

McKinney, H.H. 1929. Mosaic diseases in the Canary Islands, West Africa, and Gibraltar. J. Agr. Res. 39:557-578.
Michelmore, R.W., I. Paran, and R.V. Kesseli. 1991. Identification of markers linked to disease resistance genes by bulked segregant analysis: A rapid method to detect markers in specific genomic regions using segregating populations. Proc. Natl. Acad. Sci. USA 88:9828-9832.

Mutschler, M.A. and W.M. Wintermantel. 2006. Reducing virus associated with crop loss through resistance to insect vectors, $\mathrm{p}$. 241-260. In: G. Loebenstein, G. and J.P. Carr (eds.). Natural resistance mechanisms of plants to viruses. Akadémiai Kiadó, Budapest, Hungary.

Nieto, C., M. Morales, G. Orjeda, C. Clepet, A. Monfort, B. Sturbois, P. Puigdomènech, M. Pitrat, M. Caboche, C. Dogimont, J. GarciaMas, M.A. Aranda, and A. Bendahmane. 2006. An eIF4E allele confers resistance to an uncapped and non-polyadenylated RNA virus in melon. Plant J. 48:452-462.

Prins, M., M. Laimer, E. Noris, J. Schubert, M. Wasseneggar, and M. Tepfer. 2008. Strategies for antiviral resistance in transgenic plants. Mol. Plant Pathol. 9:73-83.

Provvidenti, R. 1991. Inheritance of resistance to the Florida strain of zucchini yellow mosaic virus in watermelon. HortScience 26: 407-408.

Provvidenti, R., D. Gonsalves, and H.S. Humaydan. 1984. Occurrence of zucchini yellow mosaic virus in cucurbits from Connecticut, New York, Florida, and California. Plant Dis. 68:443-446.

Rangel, P.N., R.P.V. Brondani, A.S.G. Coelho, P.H. Rangel, and C. Brondani. 2007. Comparative linkage mapping of Oryza glumaepatula and Oryza sativa interspecific crosses based on microsatellite and expressed sequence tag markers. Genet. Mol. Biol. 30:1415-1417.

Robaglia, C. and C. Caranta. 2006. Translation initiation factors: A weak link in plant RNA virus infection. Trends Plant Sci. 11:40-45.

Ruffel, S., J.L. Gallois, M.L. Lesage, and C. Caranta. 2005. The recessive potyvirus resistance gene pot-1 is the tomato orthologue of the pepper pvr2-eIF4E gene. Mol. Genet. Genomics 274:346-353.

Sherf, A.I. and A.A. Macnab. 1986. Vegetable diseases and their control. 2nd ed. Wiley, New York.

Strange, E.B., N. Guner, Z. Pesic-VanEsbroeck, and T.C. Wehner. 2002. Screening the watermelon germplasm collection for resistance to papaya ringspot virus type-W. Crop Sci. 42:1324-1330.

U.S. Department of Agriculture. 2007. Agricultural prices 2006 summary. 15 July 2009. <http://usda.mannlib.cornell.edu/usda/nass/ CropValuSu//2000s/2007/CropValuSu-02-15-2007.pdf $>$.

Van Ooijen, J.W. and R.E. Voorips. 2001. JoinMap® 3.0, Software for the calculation of genetic linkage maps. Plant Research International, Wageningen, The Netherlands.

Xu, Y., D. Kang, Z. Shi, H. Shen, and T. Wehner. 2004. Inheritance of resistance to zucchini yellow mosaic virus and watermelon mosaic virus in watermelon. J. Hered. 95:498-502.

Yi, Y.J., H.Y. Liu, X.Q. Huang, L.Z. An, F. Wang, and X.L. Wang. 2008. Development of molecular markers linked to the wheat powdery mildew resistance gene $\mathrm{Pm} 4 \mathrm{~b}$ and marker validation for molecular breeding. Plant Breed. 127:116-120. 